\title{
Orchidftgra
}

Vol. 1, No. 1, Bulan Februari Tahun 2021

DOI: http://dx.doi.org/10.35138/orchidagro.v1.i1.230

\section{Pengaruh Konsentrasi Jus Lidah Buaya (Aloe cbinensis Baker) Terhadap Pertumbuhan Planlet Anggrek Hasil Silangan Dendrobium Morning Sun X Dendrobium Samarai}

The Effect of Aloevera juice (Aloe cbinensis Baker) Towards Grow of Organized Planlet Cross Dendrobium Morning Sun X Dendrobium Samarai

Reo Sempana, Lia Amalia, Wahyono Widodo, Suparman, Elly Roosma Ria, Noertjahyani

Program Studi Agroteknologi Fakultas Pertanian, Universitas Winaya Mukti

Email: reo.sempana@gmail.com

(Received: 22-12-20; Published: 20-02-21)

\begin{abstract}
ABSTRAK
Percobaan ini bertujuan untuk mempelajari pengaruh pemberian konsentrasi jus lidah buaya serta mendapatkan konsentrasi jus lidah buaya yang menunjukkan pertumbuhan jumlah daun dan jumlah akar lebih baik pada planlet anggrek Dendrobium hasil silangan secara in vitro. Percobaan ini dilaksanakan di Laboratorium Kultur Jaringan, Fakultas Pertanian, Universitas Winaya Mukti yang dimulai pada bulan Mei sampai Agustus 2019. Rancangan percobaan yang digunakan adalah Rancangan Acak Lengkap dengan 5 perlakuan yang diulang 5 kali. Konsentrasi jus lidah buaya yang digunakan yaitu perlakuan A (0 g L ${ }^{-1}$ larutan), B (25 $\mathrm{g} \mathrm{L}^{-1}$ larutan), C (50 $\mathrm{g} \mathrm{L}^{-1}$ larutan), D (75 $\mathrm{g} \mathrm{L}^{-1}$ larutan), dan $\mathrm{E}$ (100 g L ${ }^{-1}$ larutan). Berdasarkan penelitian yang telah dilakukan menunjukkan konsentrasi jus lidah buaya B (25 g L $\left.{ }^{-1} \mathrm{Larutan}\right), \mathrm{C}\left(50 \mathrm{~g} \mathrm{~L}{ }^{-1}\right.$ larutan), D (75 $\mathrm{g} \mathrm{L}^{-1}$ larutan) menghasilkan tinggi planlet, jumlah tunas, jumlah akar, dan panjang akar lebih baik dibanding dengan konsentrasi lainnya.
\end{abstract}

Kata kunci : Anggrek Dendrobium, Jus lidah buaya, Planlet.

\begin{abstract}
This experiment aims was to study the effect of the concentration of aloe vera juice and to get the concentration of aloe vera juice which shows better growth of the number of leaves and the number of roots on the Dendrobium orchid plantlet in Hybrid-vitro results. This experiment was carried out at the Tissue Culture Laboratory, Faculty of Agriculture, Winaya Mukti University, which began in May to August 2019. The experimental design was used a Completely Randomized Design with 5 treatments in 5 replications and the treatments namely: A $\left(0 \mathrm{~g} \mathrm{~L}^{-1}\right.$ solution), $B\left(25 \mathrm{~g} \mathrm{~L}^{-1}\right.$ solution), $C\left(50 \mathrm{~g} \mathrm{L^{-1 }}\right.$ solution), D (75 $\mathrm{g} \mathrm{L} \mathrm{L}^{-1}$ solution), E (100 $\mathrm{g} \mathrm{L}^{-1}$ solution). The results showed that consentration of B (25 $\mathrm{g} \mathrm{L}^{-1}$ solution), $C$ (50 $\mathrm{g} \mathrm{L}^{-1}$ solution), D (75 $\mathrm{g} L^{-1}$ solution) gave plantlet height, number of shoots, number of roots, and root length better than another treatments.
\end{abstract}

Keywords: Aloe vera juice, Dendrobium orchid, Planlet. 


\section{PENDAHULUAN}

Indonesia memiliki jumlah anggrek lebih dari 5.000 jenis anggrek yang tersebar di beberapa pulau (Andiani, 2018). Anggrek Dendrobium merupakan anggrek yang dapat digunakan untuk dekorasi atau penghias ruangan karena memiliki bentuk bunga yang beragam. Kebutuhan akan bunga potong di Indonesia mencapai lebih dari 21 juta tangkai yang pada tahun 2015 angka produksi sebesar 21.513.280 dan pada tahun 2016 produksi bunga potong menurun sebesar 19.978.078. Selain itu, produktivitas tanaman anggrek menurun sebesar 24,08 \% menyebabkan kebutuhan anggrek masih belum terpenuhi secara menyeluruh (Badan Pusat Statistik, 2017).

Gunawan (1990) menyatakan bahwa, perbanyakan tanaman anggrek dengan biji sulit dilakukan dengan cara konvensional karena biji anggrek memiliki komposisi endosperm yang tidak lengkap. Oleh karena itu, ketersediaan tanaman anggrek dalam waktu yang singkat dan mampu menghasilkan jumlah yang banyak perlu diupayakan dengan melakukan peningkatan produksi benih tanaman anggrek agar keberadaannya tetap dapat dinikmati untuk memenuhi kebutuhan dalam negeri (Widiastoety et al., 2009).

Budidaya in vitro merupakan teknik perbanyakan tanaman dengan cara mengisolasi bagian tanaman seperti daun, mata tunas, serta menumbuhkan bagian-bagian tersebut dalam media buatan secara aseptik yang kaya nutrisi dan zat pengatur tumbuh dalam wadah tertutup yang tembus cahaya sehingga bagian tanaman dapat memperbanyak diri dan bergenerasi menjadi tanaman lengkap. Prinsip utama dari teknik budidaya in vitro adalah perbanyakan bagian vegetatif tanaman pada media buatan yang dilakukan di tempat steril (Zulkarnian, 2009).

Media merupakan faktor penentu dalam perbanyakan dengan budidaya in vitro. Penggunaan media dengan penambahan bahan organik cenderung memberikan jumlah organ tunas, daun dan akar yang tumbuh lebih optimal dari pada menggunakan media VW saja (Rahma et al., 2018).

Lidah buaya dapat dipergunakan sebagai suplemen hidroponik dan dimanfaatkan dalam penambahan nutrisi pada media kultur jaringan
(Purnami et al., 2014). Pertumbuhan tanaman lidah buaya (Aloe vera) dengan konsentrasi $0,05 \mathrm{ppm}$ dan $1,00 \mathrm{ppm}$ NAA menghasilkan pertumbuhan akar dan pertumbuhan tunas terbaik (Darini, 2015).

Lidah buaya mengandung kalsium $(\mathrm{Ca})$ dan magnesium $(\mathrm{Mg})$ yang berperan dalam meningkatkan metabolisme serta pembentukan klorofil pada daun dan mendukung pertumbuhan sel dan jaringan tanaman.

\section{METODE PENELITIAN}

Percobaan ini dilakukan dengan metode percobaan (eksperimen), dimulai pada bulan Mei sampai Agustus 2019, bertempat di Laboratorium kultur jaringan, Fakultas Pertanian Universitas Winaya Mukti Sumedang. Rancangan lingkungan yang digunakan adalah Rancangan Acak Lengkap (RAL) dengan 5 perlakuan yang diulang 5 kali. Total botol keseluruhan terdapat 100 botol dan masing-masing botol diisi 2 planlet anggrek Dendrobium.

Pengamatan utama yaitu pengamatan yang dilakukan dengan uji analisis data secara statistika meliputi tinggi planlet (mm), jumlah tunas, jumlah daun (helai), jumlah akar (buah), panjang akar (mm), jumlah klorofil (unit). Tahapan sterilisasi botol dimulai dari pencucian botol terlebih dahulu yang dilakukan dengan sikat khusus botol ke seluruh bagian botol. Kemudian botol ditutup dengan tutup karet yang khusus budidaya in vitro dan ditambah dengan plastik kemudian diikat dengan karet gelang. Sterilisasi botol ke dalam autoklaf untuk dilakukan sterilisasi pada suhu $121^{\circ} \mathrm{C}$ dengan tekanan 17,5 psi (Pound Per Square Inci) selama 20 menit.

Penghalusan lidah buaya menggunakan blender dilakukan secara terpisah pada masingmasing perlakuan yang ditambahkan $100 \mathrm{ml}$ air untuk mempermudah proses penghalusan daging lidah buaya. Pembuatan media dilakukan dengan menimbang semua bahan yaitu media VW 1,67 $\mathrm{g}$, ditambahkan dengan agar-agar $7 \mathrm{~g}$, gula pasir $20 \mathrm{~g}$, PPM 0,5 ml, dan arang aktif 2 g. Semua bahan tersebut dimasukkan ke beaker glass kemudian ditambahkan jus lidah buaya sesuai dengan perlakuan, yaitu perlakuan A $0 \mathrm{~g} \mathrm{~L}^{-1}$ larutan VW, B $25 \mathrm{~g} \mathrm{~L}^{-1}$ larutan, $\mathrm{C} 50 \mathrm{~g} \mathrm{~L}^{-1}$ larutan, D $75 \mathrm{~g} \mathrm{~L}^{-1}$ larutan, E $100 \mathrm{~g} \mathrm{~L}^{-1}$ larutan. Setiap 
media yang telah masak dilakukan pengukuran $\mathrm{pH}$ menggunakan $\mathrm{pH}$ universal. Penentuan $\mathrm{pH}$ ini menurut (Pierik, 1971), pada umumnya kemasaman medium ditetapkan antara 5,6-5,8. Sterilisasi dilakukan dengan autoklaf pada suhu $121^{\circ} \mathrm{C}$ dengan tekanan 17,5 psi selama 20 menit.

\section{HASIL DAN PEMBAHASAN}

\section{1) Tinggi Planlet}

Pengamatan pengaruh konsentrasi jus lidah buaya terhadap tinggi planlet menunjukkan berbeda

Tabel 1. Pengaruh Konsentrasi Jus Lidah Buaya terhadap Tinggi Planlet Umur 4, 8, dan 12 MSK

\begin{tabular}{lccc}
\hline \multicolumn{1}{c}{ Perlakuan } & \multicolumn{3}{c}{ Tinggi Planlet $(\mathrm{mm})$} \\
\cline { 2 - 4 } & $4 \mathrm{MSK}$ & $8 \mathrm{MSK}$ & $12 \mathrm{MSK}$ \\
\hline A $\left(0 \mathrm{~g} \mathrm{~L}^{-1}\right.$ Larutan $)$ & $9,90 \mathrm{a}$ & $11,35 \mathrm{a}$ & $15,90 \mathrm{a}$ \\
$\mathrm{B}\left(25 \mathrm{~g} \mathrm{~L}^{-1}\right.$ Larutan $)$ & $13,10 \mathrm{~b}$ & $18,85 \mathrm{~b}$ & $24,85 \mathrm{~b}$ \\
$\mathrm{C}\left(50 \mathrm{~g} \mathrm{~L}^{-1}\right.$ Larutan$)$ & $12,10 \mathrm{ab}$ & $15,10 \mathrm{ab}$ & $24,50 \mathrm{ab}$ \\
$\mathrm{D}\left(75 \mathrm{~g} \mathrm{~L}^{-1}\right.$ Larutan$)$ & $12,40 \mathrm{ab}$ & $16,15 \mathrm{~b}$ & $23,20 \mathrm{~b}$ \\
$\mathrm{E}\left(100 \mathrm{~g} \mathrm{~L}^{-1}\right.$ Larutan $)$ & $9,45 \mathrm{a}$ & $11,10 \mathrm{a}$ & $13,25 \mathrm{a}$
\end{tabular}

Keterangan : Angka rata-rata yang diikuti huruf yang sama pada kolom yang sama menunjukkan berbeda tidak nyata menurut Uji Jarak Berganda Duncan pada taraf nyata 5\%.

Pada umur 4 MSK perlakuan B $\left(25 \mathrm{~g} \mathrm{~L}^{-1}\right.$ Larutan) menunjukkan hasil yang berbeda nyata dibanding perlakuan A $\left(0 \mathrm{~g} \mathrm{~L}^{-1}\right.$ Larutan $)$ dan $\mathrm{E}$ (100 $\mathrm{g} \mathrm{L}^{-1}$ Larutan) tetapi berbeda tidak nyata dibanding perlakuan $\mathrm{C}\left(50 \mathrm{~g} \mathrm{~L}^{-1}\right.$ Larutan) dan $\mathrm{D}$ (75 g L L $\mathrm{L}^{-1}$ Larutan). Pada umur 8 MSK menunjukkan perlakuan B (25 $\mathrm{g} \mathrm{L}^{-1}$ Larutan) dan $\mathrm{D}\left(75 \mathrm{~g} \mathrm{~L}^{-1}\right.$ Larutan) menunjukkan hasil yang berbeda nyata dibanding perlakuan A ( $0 \mathrm{~g}$ $\mathrm{L}^{-1}$ Larutan) dan $\mathrm{E}$ (100 $\mathrm{g} \mathrm{L}^{-1}$ Larutan), dan berbeda tidak nyata dengan perlakuan $\mathrm{C}\left(50 \mathrm{~g} \mathrm{~L}^{-}\right.$ ${ }^{1}$ Larutan) terhadap tinggi planlet. Pada umur 12 MSK, perlakuan B (25 g L-1 Larutan), C (50 g L1 Larutan), dan $\mathrm{D}$ (75 $\mathrm{g} \mathrm{L}^{-1}$ Larutan ) menunjukkan hasil yang berbeda nyata dibanding dengan perlakuan $\mathrm{A}\left(0 \mathrm{~g} \mathrm{~L}^{-1}\right.$ Larutan $)$

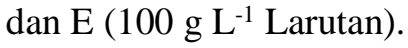

Berdasarkan hasil penelitian yang telah dilakukan diketahui bahwa pengaruh pemberian

Pengamatan pengaruh konsentrasi jus lidah buaya terhadap jumlah tunas menunjukkan berbeda nyata pada umur 4, 8, dan 12 MSK. Pada umur 4 MSK perlakuan D (75 $\mathrm{g} \mathrm{L}^{-1}$ Larutan) dan B (25 $\mathrm{g} \mathrm{L}^{-1}$ Larutan) menunjukkan hasil yang berbeda nyata dibanding perlakuan $\mathrm{C}$ jus lidah buaya pada konsentrasi B $\left(25 \mathrm{~g} \mathrm{~L}^{-1}\right.$ Larutan) menunjukkan hasil yang berbeda nyata pada umur 4, 8, dan 12 MSK karena pada kandungan jus lidah buaya terdapat hormon organik berupa auksin dan hormon tersebut mampu mendukung proses pertumbuhan tinggi planlet.

Sesuai dengan Dwi (2008) yang menyebutkan bahwa fungsi auksin dapat mempengaruhi pertumbuhan panjang batang tanaman. Dalam proses ini kandungan vitamin $\mathrm{B}_{1}$ pada lidah buaya berperan sebagai zat yang membantu tanaman dalam beradaptasi dalam lingkungan tumbuh yang baru. Purnami et al., (Purnami et al., 2014) menyatakan bahwa vitamin $\mathrm{B}_{1}$ mampu mengurangi tekanan akibat pergantian media tumbuh tanaman.

\section{2) Jumlah Tunas}

(50 $\mathrm{g} \mathrm{L}^{-1}$ Larutan) dan E (100 $\mathrm{g} \mathrm{L}^{-1}$ Larutan). Tetapi berbeda tidak nyata dibanding perlakuan A (0 $\mathrm{g} \mathrm{L}^{-1}$ Larutan) dan. Pada umur 8 MSK menunjukkan perlakuan $\mathrm{B}$ ( $25 \mathrm{~g} \mathrm{~L}^{-1}$ Larutan) dan $\mathrm{D}$ (75 $\mathrm{g} \mathrm{L}^{-1}$ Larutan) menunjukkan hasil yang berbeda tidak nyata dibanding perlakuan A 
(0 $\mathrm{g} \mathrm{L}^{-1}$ Larutan), C (50 $\mathrm{g} \mathrm{L}^{-1}$ Larutan), tetapi berbeda nyata dengan perlakuan $\mathrm{E}\left(100 \mathrm{~g} \mathrm{~L}^{-1}\right.$ Larutan). Pada umur 12 MSK menunjukkan perlakuan B (25 $\mathrm{g} \mathrm{L}^{-1}$ Larutan) dan D (75 $\mathrm{g} \mathrm{L}^{-1}$
Larutan) menunjukkan hasil yang berbeda nyata dibanding perlakuan $\mathrm{C}\left(50 \mathrm{~g} \mathrm{~L}^{-1}\right.$ Larutan) dan $\mathrm{E}$ (100 $\mathrm{g} \mathrm{L}^{-1}$ Larutan).

Tabel 2. Pengaruh Konsentrasi Jus Lidah Buaya terhadap Jumlah Tunas Umur 4, 8, dan 12 MSK

\begin{tabular}{lccc}
\hline \multirow{2}{*}{ Perlakuan } & \multicolumn{3}{c}{ Jumlah Tunas } \\
\cline { 2 - 4 } & $4 \mathrm{MSK}$ & $8 \mathrm{MSK}$ & $12 \mathrm{MSK}$ \\
\hline $\mathrm{A}\left(0 \mathrm{~g} \mathrm{~L}^{-1}\right.$ Larutan $)$ & $0,80 \mathrm{ab}$ & $0,65 \mathrm{ab}$ & $1,45 \mathrm{ab}$ \\
$\mathrm{B}\left(25 \mathrm{~g} \mathrm{~L}^{-1}\right.$ Larutan $)$ & $0,96 \mathrm{~b}$ & $1,40 \mathrm{~b}$ & $2,45 \mathrm{~b}$ \\
$\mathrm{C}\left(50 \mathrm{~g} \mathrm{~L}^{-1}\right.$ Larutan $)$ & $0,74 \mathrm{a}$ & $0,30 \mathrm{ab}$ & $0,45 \mathrm{a}$ \\
$\mathrm{D}\left(75 \mathrm{~g} \mathrm{~L}^{-1}\right.$ Larutan $)$ & $0,97 \mathrm{~b}$ & $1,60 \mathrm{~b}$ & $2,60 \mathrm{~b}$ \\
$\mathrm{E}\left(100 \mathrm{~g} \mathrm{~L}^{-1}\right.$ Larutan $)$ & $0,71 \mathrm{a}$ & $0,05 \mathrm{a}$ & $0,10 \mathrm{a}$ \\
\hline
\end{tabular}

Keterangan : Angka rata-rata yang diikuti huruf yang sama pada kolom yang sama menunjukkan berbeda tidak nyata menurut Uji Jarak Berganda Duncan pada taraf nyata 5\%.

Pertumbuhan jumlah tunas pada umur 12 MSK menunjukkan hasil yang berbeda nyata pada konsentrasi B (25 $\mathrm{g} \mathrm{L}^{-1}$ Larutan) dan D (75 $\mathrm{g} \mathrm{L}^{-1}$ Larutan). Diduga hal tersebut dikarenakan jumlah sitokinin yang terkandung dalam jus lidah buaya lebih besar dibanding dengan auksin.

Karjadi dan Buchory (2008) yang menyatakan bahwa sitokinin digunakan untuk merangsang pembentukan tunas. Proses regenerasi dan pembentukan tunas sangat ditentukan oleh keseimbangan nutrisi dalam formulasi media yang digunakan. Pemberian sitokinin menunjukkan hasil terbaik pada jumlah tunas, dan jumlah daun tanaman Tribulus terrestris L (Akhiriana et al., 2019).

Berdasarkan pengamatan yang telah dilakukan, pada perlakuan D (75 $\mathrm{g} \mathrm{L}^{-1}$ Larutan) terdapat munculnya kalus yang belum

Tabel 3. Pengaruh Konsentrasi Jus Lidah Buaya terhadap Jumlah Daun pada Umur 4, 8, dan 12 MSK

\begin{tabular}{lccc}
\hline \multirow{2}{*}{ Perlakuan } & \multicolumn{3}{c}{ Jumlah Daun (helai) } \\
\cline { 2 - 4 } & $4 \mathrm{MSK}$ & $8 \mathrm{MSK}$ & $12 \mathrm{MSK}$ \\
\hline $\mathrm{A}\left(0 \mathrm{~g} \mathrm{~L}^{-1}\right.$ Larutan $)$ & $2,55 \mathrm{a}$ & $2,60 \mathrm{a}$ & $3,40 \mathrm{a}$ \\
$\mathrm{B}\left(25 \mathrm{~g} \mathrm{~L}^{-1}\right.$ Larutan $)$ & $2,75 \mathrm{a}$ & $3,30 \mathrm{a}$ & $4,55 \mathrm{~b}$ \\
$\mathrm{C}\left(50 \mathrm{~g} \mathrm{~L}^{-1}\right.$ Larutan $)$ & $2,40 \mathrm{a}$ & $3,20 \mathrm{a}$ & $3,90 \mathrm{ab}$ \\
$\mathrm{D}\left(75 \mathrm{~g} \mathrm{~L}^{-1}\right.$ Larutan $)$ & $2,15 \mathrm{a}$ & $2,90 \mathrm{a}$ & $3,65 \mathrm{ab}$ \\
$\mathrm{E}\left(100 \mathrm{~g} \mathrm{~L}^{-1}\right.$ Larutan $)$ & $2,25 \mathrm{a}$ & $2,80 \mathrm{a}$ & $3,30 \mathrm{a}$ \\
\hline
\end{tabular}

Keterangan : Angka rata-rata yang diikuti huruf yang sama pada kolom yang sama menunjukkan berbeda tidak nyata menurut Uji Jarak Berganda Duncan pada taraf nyata 5\%.

Pada umur 12 MSK perlakuan B (25 g

$\mathrm{L}^{-1}$ Larutan) menunjukkan hasil yang berbeda membentuk tunas. Diduga pertumbuhan kalus didukung oleh adanya kandungan auksin pada jus lidah buaya. Didukung oleh Azizah (2017) bahwa auksin memiliki peran terhadap pembentukan kalus.

Penambahan arang aktif proanalis sebanyak $2 \mathrm{~g} / \mathrm{l}$ kedalam media kultur dapat meningkatkan jumlah tunas anakan yang terbentuk. Hal ini yang pada akhirnya juga mempengaruhi semakin bertambahnya bobot basah plantlet anggrek (Tuhuteru et al., 2018).

\section{3) Jumlah Daun}

Pengamatan pengaruh konsentrasi jus lidah buaya terhadap jumlah daun menunjukkan berbeda tidak nyata pada umur 4 dan 8 MSK. Pada umur 12 MSK menunjukkan hasil yang berbeda nyata pada jumlah daun. nyata dengan perlakuan A ( $0 \mathrm{~g} \mathrm{~L}^{-1}$ Larutan) dan $\mathrm{E}\left(100 \mathrm{~g} \mathrm{~L}^{-1}\right.$ Larutan) tetapi berbeda tidak nyata dengan perlakuan C (50 $\mathrm{g} \mathrm{L}^{-1}$ Larutan) dan D (75 
g $\mathrm{L}^{-1}$ Larutan). Sesuai dengan penelitian Hartati, Budiyono, dan Cahyono (2016) pemberian auksin dan sitokinin berpengaruh tidak nyata terhadap jumlah daun anggrek Dendrobium sp, diduga penambahan sitokinin

\section{4) Jumlah Akar}

Pengamatan pengaruh konsentrasi jus lidah buaya terhadap jumlah akar menunjukkan berbeda nyata pada umur 12 MSK.

Tabel 4. Pengaruh Konsentrasi Jus Lidah Buaya terhadap Jumlah Akar Umur 12 MSK

\begin{tabular}{lc}
\hline \multicolumn{1}{c}{ Perlakuan } & $\begin{array}{c}\text { Jumlah Akar (buah) } \\
12 \mathrm{MSK}\end{array}$ \\
\hline $\mathrm{A}\left(0 \mathrm{~g} \mathrm{~L}^{-1}\right.$ Larutan $)$ & $1,97 \mathrm{~b}$ \\
$\mathrm{~B}\left(25 \mathrm{~g} \mathrm{~L}^{-1}\right.$ Larutan $)$ & $2,55 \mathrm{~b}$ \\
$\mathrm{C}\left(50 \mathrm{~g} \mathrm{~L}^{-1}\right.$ Larutan $)$ & $2,39 \mathrm{~b}$ \\
$\mathrm{D}\left(75 \mathrm{~g} \mathrm{~L}^{-1}\right.$ Larutan $)$ & $2,37 \mathrm{~b}$ \\
$\mathrm{E}\left(100 \mathrm{~g} \mathrm{~L}^{-1}\right.$ & $1,16 \mathrm{a}$ \\
Larutan $)$ &
\end{tabular}

Keterangan : Angka rata-rata yang diikuti huruf yang sama menunjukkan berbeda tidak nyata menurut Uji Jarak Berganda Duncan pada taraf nyata $5 \%$.

Pada umur 12 MSK pertumbuhan jumlah akar menunjukkan hasil yang berbeda nyata diduga pemberian perlakuan mempengaruhi jumlah akar yang terbentuk. Pierik et al., (2000)menyatakan fungsi utama auksin adalah untuk induksi akar dan merupakan regulator pertumbuhan efektif untuk proses pertumbuhan akar. Auksin dan sitokinin dapat mendukung pertumbuhan tunas dan akar tanaman secara in vitro (Surafel et al., 2018). Pada jus lidah buaya kandungan vitamin $B_{1}$ yang mampu memenuhi kebutuhan pertumbuhan jumlah akar. Vitamin $\mathrm{B}_{1}$ berperan dalam proses pertumbuhan akar apabila konsentrasi yang diberikan sesuai dengan kebutuhan tanaman.

\section{5) Panjang Akar}

Pengamatan pengaruh konsentrasi jus lidah buaya terhadap panjang akar menunjukkan berbeda nyata pada umur 12 MSK. eksogen akan berinteraksi dengan auksin endogen yang terkandung di dalam eksplan. Ini membuktikan bahwa pertumbuhan tanaman secara in vitro dikendalikan oleh keseimbangan dan interaksi antara zat pengatur tumbuh.

Tabel 5. Pengaruh Konsentrasi Jus Lidah Buaya terhadap Panjang Akar Umur 12 MSK

\begin{tabular}{lc}
\hline \multicolumn{1}{c}{ Perlakuan } & Panjang Akar $(\mathrm{mm})$ \\
& $12 \mathrm{MSK}$ \\
\hline $\mathrm{A}\left(0 \mathrm{~g} \mathrm{~L}^{-1}\right.$ Larutan $)$ & $7,60 \mathrm{~b}$ \\
$\mathrm{~B}\left(25 \mathrm{~g} \mathrm{~L}^{-1}\right.$ Larutan $)$ & $15,25 \mathrm{c}$ \\
$\mathrm{C}\left(50 \mathrm{~g} \mathrm{~L}^{-1}\right.$ Larutan $)$ & $15,20 \mathrm{c}$ \\
$\mathrm{D}\left(75 \mathrm{~g} \mathrm{~L}^{-1}\right.$ Larutan $)$ & $12,15 \mathrm{bc}$ \\
E $\left(100 \mathrm{~g} \mathrm{~L}^{-1}\right.$ Larutan $)$ & $1,30 \mathrm{a}$
\end{tabular}

Keterangan : Angka rata-rata yang diikuti huruf yang sama menunjukkan berbeda tidak nyata menurut Uji Jarak Berganda Duncan pada taraf nyata 5\%.

Penggunaan jus lidah buaya memiliki pengaruh terhadap panjang akar pada umur $12 \mathrm{MSK}$. Perlakuan B $\left(25 \mathrm{~g} \mathrm{~L}^{-1}\right.$ Larutan) dan $\quad \mathrm{C} \quad\left(\begin{array}{llll}50 & \mathrm{~g} & \mathrm{~L}^{-1} & \text { Larutan }\end{array}\right)$ menunjukkan hasil yang berbeda nyata dibanding dengan perlakuan A $\left(0 \mathrm{~g} \mathrm{~L}^{-1}\right.$ Larutan) dan $\mathrm{E} \quad\left(100 \mathrm{~g} \quad \mathrm{~L}^{-1}\right.$ Larutan). Perlakuan B (25 g L ${ }^{-1}$ Larutan) berbeda tidak nyata dengan perlakuan $\mathrm{D}\left(75 \mathrm{~g} \mathrm{~L}^{-1}\right.$ Larutan). Perlakuan E (100 g L $\mathrm{L}^{-1}$ Larutan) berbeda nyata dengan seluruh perlakuan. Hal ini diduga karna perlakuan A $\left(0 \mathrm{~g} \mathrm{~L}^{-1}\right.$ Larutan) tidak mengandung hormon auksin eksogen sendang pada perlakuan E (100 g L ${ }^{1}$ Larutan) hormon auksin yang terkandung di dalam lidah buaya tinggi menjadikan terhambatnya proses pertumbuhan akar. Sesuai pendapat Salisbury dan Ross (1992) bahwa konsentrasi zat pengatur tumbuh yang terlalu tinggi untuk satu jenis tanaman tertentu akan mendorong sintesis etilen yang kemudian menghambat pemanjangan akar Didukung oleh Siraj (2016) yang menyatakan bahwa pemberian zat pengatur tumbuh auksin pada media MS berpengaruh terhadap jumlah akar dan panjang akar pada anggrek Dendrobium bensoniae dan Dendrobium aphyllum. 


\section{6) Jumlah Klorofil}

Pengamatan pengaruh konsentrasi jus lidah buaya terhadap jumlah klorofil menunjukkan berbeda tidak nyata pada umur 12 MSK.

Tabel 6. Pengaruh Konsentrasi Jus Lidah Buaya terhadap Jumlah Klorofil Umur 12 MSK

\begin{tabular}{|c|c|}
\hline Perlakuan & $\begin{array}{l}\text { Jumlah Klorofil (unit) } \\
12 \mathrm{MSK}\end{array}$ \\
\hline A (0 $\mathrm{g} \mathrm{L}^{-1}$ Larutan $)$ & $11,13 \mathrm{a}$ \\
\hline B (25 $\mathrm{g} \mathrm{L}^{-1}$ Larutan $)$ & $14,87 \mathrm{a}$ \\
\hline $\mathrm{C}\left(50 \mathrm{~g} \mathrm{~L}^{-1}\right.$ Larutan $)$ & $11,65 \mathrm{a}$ \\
\hline D (75 $\mathrm{g} \mathrm{L}^{-1}$ Larutan) & $15,83 \mathrm{a}$ \\
\hline $\mathrm{E}\left(100 \mathrm{~g} \mathrm{~L}^{-1}\right.$ Larutan $)$ & $12,86 \mathrm{a}$ \\
\hline $\begin{array}{r}\text { Keterangan : Angka rata } \\
\text { sama } \\
\text { nyata } \\
\text { Duncan }\end{array}$ & $\begin{array}{l}\text { yang diikuti huruf yang } \\
\text { ajukkan berbeda tidak } \\
\text { ut Uji Jarak Berganda } \\
\text { taraf nyata } 5 \% \text {. }\end{array}$ \\
\hline
\end{tabular}

Penggunaan jus lidah buaya memiliki pengaruh berbeda tidak nyata terhadap jumlah

\section{KESIMPULAN DAN SARAN}

\section{Kesimpulan}

Berdasarkan penelitian yang telah dilakukan dapat disimpulkan bahwa, perlakuan konsentrasi jus lidah buaya berpengaruh terhadap pertumbuhan tinggi planlet umur 4, 8, 12 MSK, jumlah tunas umur 4, 8, 12 MSK, jumlah akar dan panjang akar pada umur 12 MSK, tetapi tidak berpengaruh terhadap jumlah daun dan jumlah klorofil. Dan Perlakuan konsentrasi B (25 g L-1 Larutan), C (50 g $\mathrm{L}^{-1}$ Larutan), dan D (75 $\left.\mathrm{g} \mathrm{L}^{-1}\right)$ Larutan menghasilkan tinggi planlet, jumlah tunas, jumlah akar dan panjang akar lebih baik.

\section{Saran}

Konsentrasi B (25 $\mathrm{g} \mathrm{L}^{-1}$ Larutan) dapat disarankan untuk memperoleh pertumbuhan tinggi planlet, jumlah tunas, jumlah akar dan panjang akar yang lebih baik. Serta perlu dilakukan penelitian tentang penggunaan setengah media VW yang ditambahkan jus lidah buaya. klorofil pada umur 12 MSK. Pada jumlah klorofil umur 12 MSK menunjukkan hasil yang berbeda tidak nyata karena kandungan $\mathrm{Mg}$ dan $\mathrm{Ca}$ pada media tanam sudah mampu mendukung pertumbuhan jumlah klorofil pada tanaman dan diduga tinggi rendahnya klorofil berkaitan dengan hasil dari fotosintesis. Semakin tinggi pertumbuhan vegetatif maka semakin tinggi juga kandungan klorofil yang terkandung di daun walau pun dari uji klorofil ini tidak ada yang tertinggi, tetapi dari pengamatan vegetatif tinggi planlet menunjukkan hasil yang nyata dengan penambahan jus lidah buaya tersebut. Sependapat dengan Thamrin (2008) menyatakan bahwa kandungan klorofil yang tinggi mampu mendorong proses fotosintesis tanaman sehingga fotosintat yang dihasilkan akan banyak, dan pertumbuhan vegetatif tanaman (tinggi tanaman) lebih pesat.

\section{DAFTAR PUSTAKA}

Akhiriana, E., Samanhudi, and A. Yunus. 2019. Coconut Water And IAA Effect On The In Vitro Growth Of Tribulus Terrestris L. Acta Univ. Agric. Mendelianae Brun. 67(1): 1-18. Andiani, Y. 2018. Usaha Pembibitan Anggrek dalam Botol (Teknik in vitro). Pustakka Baru Press.

Azizah, R. 2017. Pertumbuhan Kalus Kopi Liberika Tungkal Jambi (Coffaea Liberica Var. Liberica CV. Tungkal Jambi) dengan Kombinasi 2,4-D dan Kinetin Secara in vitro.

Darini, M.T. 2015. Optimalisasi Zat Pengatur Tumbuh NAA dan BAP terhadap Pertumbuhan Eksplan Tanaman Lidah Buaya. Acta Univ. Agric. Silvic. Mendelianae Brun. 53(9):1689-1699.

http://dx.doi.org/10.1016/j.precamres.2014.2.

Dwi, I.R. 2008. Peranan Dan Fungsi Hormon Bagi Pertumbuhan Tanaman.

Gunawan, L.W. 1990. Budidaya Anggrek. Penebar Swadaya.

Hartati, S., A. Budiono, and O. Cahyono. 2016. Pengaruh NAA dan BAP terhadap Pertumbuhan Sub Kultur Anggrek Hasil 
Persilangan Dendrobium Biggibum $\mathrm{X}$ Dendrobium Liniale. J. Sustain Agric 31(1): 33-37.

Karjadi, A.K., and A. Buchory. 2008. Pengaruh Auksin dan Sitokinin terhadap Pertumbuhan dan Perkembangan Jaringan Meristem Kentang Kultivar Granola. J. Hort 18(4): 380.

Pierik, H.S., M.J. Dejue, and E. Jacobsen. 2000. Plant Tissue Culture. Sci. Hortic. 85(6): 307318.

Purnami, N.L.G.W., H. Yuswanti, and A.A.M. Astiningsih. 2014. Pengaruh Jenis dan Frekuensi Penyemprotan Leri Terhadap Pertumbuhan Benih Anggrek Phalaenopsis sp. Pasca Aklimatisasi. EJurnal Agroteknologi Trop. 3(1): 22-31.

Rahma, S., T. Rahayu, and A. Hayati. 2018. Kajian Penambahan Bahan Organik Pada Media Tanam VW Pada Organogenesis Anggrek Dendrobium Secara In vitro. E-jurnal Ilm. 1(1): 93-103.

Salisbury, F.B., and C.W. Ross. 1992. Fisiologi Tumbuhan. Bandung.

Siraj, S.R. 2016. In Vitro Regeneration and Rapid Multiplication of Two Orchid Varieties of
Dendrobium bensoniae and Dendrobium aphyllum.

Statistik, B.P. 2017. Statistik Pertanian. Kementrian Pertan.

Surafel, Shibru, G. Olani, and A. Dabebe. 2018. In Vitro Propagation of Aloe Vera Linn From Shoot Tip Culture. GSC Biol. Pharm. Sci. 4(2): 001-006.

Thamrin, M. 2008. Peningkatan Pembungaan Jeruk Pamelo (Citrus Grandis (L.) Osbeck) "Cikoneng" Melalui Strangulasi.

Tuhuteru, S., M.L. Hehanussa, and S.H.. Raharjo. 2018. Pertumbuhan Dan Perkembangan Anggrek Dendrobium anosmum Pada Media Kultur In Vitro Dengan Beberapa Konsentrasi Air Kelapa. Agrologia 1(1): 1-12. doi: 10.30598/a.v1i1.293.

Widiastoety, D., Solvia, and Kartikaningrum. 2009. Pengaruh Tiamin terhadap Pertumbuhan Planlet Oncidium Secara In Vitro. Cianjur. J. Hort 19(1): 35-39.

Zulkarnian. 2009. Budidaya In Vitro Tanaman, Solusi Perbanyakan Tanaman Budidaya. Jakarta. 